\title{
Quality changes of cooked sausages influenced by the incorporation of a three-component natural antioxidant blend
}

\author{
Nikolay $\mathrm{Kolev}^{1}$, Desislava Vlahova-Vangelova ${ }^{1}$, Dessislav Balev $^{1}$, and Stefan Dragoev ${ }^{1,2^{*}}$ \\ ${ }^{1}$ Department of Meat and Fish Technology, Technological Faculty, University of Food Technologies, Plovdiv, Bulgaria \\ ${ }^{2}$ Assembly of Academicians and Corresponding Members, Bulgarian Academy of Science, Sofia, Bulgaria
}

\begin{abstract}
The aim of this study was to evaluate the influence of triplicate blend of natural antioxidants on the sensorial, physicochemical and microbiological characteristics of cooked sausage. Three antioxidants: sodium L-ascorbate (x1), dihydroquercetin isolate from Larix sibirica Ledeb (x2) and lyophilized ethanol $(30 \%)$ extract of dry distilled rose (Rosa damascena Mill) petals (x3) were studied in doses $0,0.05$ and 0.1 $\mathrm{g} / \mathrm{kg}$. The sensory characteristics, $\mathrm{pH}$, primary products of lipid oxidation expressed by peroxide value and total viable count of the concentration of microorganisms were analysed. The studied parameters were measured on the first and the seventh day of the storage at $0-4^{\circ} \mathrm{C}$. After 7 days of storage at $0-4^{\circ} \mathrm{C}$ it was found that the panel evaluated the highest sensory scores in design point 9 with addition of $0.05 \mathrm{~g} / \mathrm{kg}$ of the three antioxidants and no difference was found compared to the control (without antioxidants). On the contrary, a minimum peroxide value of $2.88 \pm 0.03 \mu \mathrm{eqO} / \mathrm{kg}$ is achieved by the addition of $0.1 \mathrm{~g} / \mathrm{kg}$ of the three antioxidants. The total viable count of microorganisms and $\mathrm{pH}$ values of the control samples were lower than those with the addition of antioxidants. Additional experiments are needed to optimize the threecomponent antioxidant blend.
\end{abstract}

\section{Introduction}

The loss of meat products' quality is due to the microbiological growth and oxidative processes which leads to a decrease of the nutritional value [1]. As well as the nutritional value, the technological properties (e.g., forming an uncharacteristic consistency, decreased water holding capacity etc.) are also affected and there is a risk of accumulation of toxins and compounds that can harm the consumer's health [2]. Foodborne diseases have been reported globally which originate from oxidative changes happening first in the lipid fraction and continuing in the protein as well as solely from microbial growth [3]

Designing the products' matrix so that the new products would have the desired quality parameters has become popular for the last decade [4-5]. Incorporation of antioxidants in meat processing was necessary in order to inhibit lipid peroxidation and minimize the quality changes during storage [6]. Synthetic antioxidants have been widely used to prevent rancidity and quality loss of meat products for the past 20 years but their nature and the growing concern with the consumers require other alternatives to be sought [7-8]. On the other hand, plant extracts are rich in bioactive compounds with antioxidant activity which makes them an alternative solution to the problem [6]. These substances vary from simple molecules such as vitamin $\mathrm{C}, \mathrm{E}$ and $\mathrm{K}$, plant pigments such as carotenoids, anthocyanins but also much more complex structures like polyphenols [3].
Regulation (EC) No 1333/2008 sets the maximal levels of almost every additive used in food products [8]. Sodium L-ascorbate is largely used for its antioxidant and vitamin properties. The Siberian larch (Larix sibirica Ledeb) contains a substance of three polyphenols (dihydroquercetin approx. $96 \%$, dihydrokaempferol approx. $3 \%$ and naringenin approx. $1 \%$ ) with strong antioxidant activity [9]. Its ability to inhibit the formation of free radicals and to increase the oxidative stability of lipids in the cell membranes and its non-toxic nature make the dihydroquercetin a valuable natural antioxidant [10]. With the increase in the industrial processing of food and agricultural products, huge quantities of by-products have been generated. They are often rich in phenolic substances with antioxidant properties. This is the case with the waste rose (Rosa Damascena) petals from the rose oil production. Analysis of their composition shows a rich spectrum of more than 30 bioactive compounds with antioxidant properties [11-13]. Previous studies report a that the dried distilled rose petals extract (DDRP extract) exhibit and inhibitory effect against oxidation in relatively low concentrations [11,14].

The aim of this study was to evaluate the influence of triplicate blend of natural antioxidants on the sensorial, physicochemical and microbiological characteristics of cooked sausage.

\footnotetext{
* Corresponding author: $\underline{\log 0 s 20001 \mathrm{t} @ \text { gmail.com }}$
} 


\section{Material and methods}

\subsection{Material}

For the purpose of the experiment the preparation of the sausages was done in the training facilities of the University of Food Technology, Plovdiv, Bulgaria. The meat chilled beef and pork ( $48 \mathrm{~h}$ post mortem) $(1: 1 \mathrm{w} / \mathrm{w})$ with temperature of $1^{\circ} \mathrm{C}$ was minced to $3 \mathrm{~mm}$ by a meat grinder. The minced meat was separated into nine groups. Each of the groups was mixed in cutter machine (EMS Muller, MTK30, Saarbrucken West Germany) with premeasured quantities of natural antioxidants (Table 1), approx. 20\% (w/w) flaky ice, $22 \mathrm{~g} / \mathrm{kg}$ salt and $0.1 \mathrm{~g} / \mathrm{kg}$ sodium nitrate. The chopping continues until the temperature of the filling mass reach $12^{\circ} \mathrm{C}$. Each of the nine batches filling mass are separately stuffed in polyamide coatings with diameter of $80 \mathrm{~mm}$. For the thermal treatment is used an industrial steam boiler (Allroud-System "Rondair", Rauch and Wärmetechnik GmbH\&Co.KG, West Germany). Firstly, the roasting lasted for $30 \mathrm{~min}$ at $85-90^{\circ} \mathrm{C}$. Then the boiling is done at $76-78^{\circ} \mathrm{C}$ until the temperature in the centre of the product reach $72{ }^{\circ} \mathrm{C}$. For the cooling of the cooked sausages is used running water for 15 to $20 \mathrm{~min}$ after which they are stored in plastic cassettes without any additional package at $0-4^{\circ} \mathrm{C}$ for 7 days.

Table 1. The experimental design.

\begin{tabular}{|c|c|c|c|}
\hline $\begin{array}{c}\text { Design } \\
\text { points }\end{array}$ & $\begin{array}{c}\text { Conc. of DDRP } \\
\text { extract } \\
\left(\mathbf{x}_{\mathbf{1}}\right), \mathbf{g} / \mathbf{k g}\end{array}$ & $\begin{array}{c}\text { Conc. of } \\
\text { dihydroquercetin } \\
\left(\mathbf{x}_{\mathbf{2}}\right), \mathbf{g} / \mathbf{k g}\end{array}$ & $\begin{array}{c}\text { Conc. of sodium } \\
\text { L-ascorbate }\left(\mathbf{x}_{\mathbf{3}}\right) \mathbf{,} \\
\mathbf{g} / \mathbf{k g}\end{array}$ \\
\hline $\mathbf{1}$ & 0.00 & 0.00 & 0.00 \\
\hline $\mathbf{2}$ & 0.00 & 0.00 & 0.10 \\
\hline $\mathbf{3}$ & 0.00 & 0.10 & 0.00 \\
\hline $\mathbf{4}$ & 0.00 & 0.10 & 0.10 \\
\hline $\mathbf{5}$ & 0.10 & 0.00 & 0.00 \\
\hline $\mathbf{6}$ & 0.10 & 0.00 & 0.10 \\
\hline $\mathbf{7}$ & 0.10 & 0.10 & 0.00 \\
\hline $\mathbf{8}$ & 0.10 & 0.10 & 0.10 \\
\hline $\mathbf{9}$ & 0.05 & 0.05 & 0.05 \\
\hline
\end{tabular}

\section{$2.2 \mathrm{pH}$ determination}

Ten grams of sample were homogenized and mixed with $90 \mathrm{~mL}$ of distilled water, after $10 \mathrm{~min}$ solutions were filtered through Filtrax filter (grade 388). The $\mathrm{pH}$ of the filtrates was measured electro potentiometrically [15] using a pH meter "Microsyst MS 2004" (Microsyst, Plovdiv) equipped with a temperature and combined $\mathrm{pH}$ electrode type "Sensorex".

\subsection{The total lipid extraction and determination of peroxide value}

The extraction of total lipids was performed by the method of Bligh and Dyer [16]. The peroxide value (POV) expressed that the levels of lipid hydroperoxides were determined by the oxidation of $\mathrm{Fe}^{2+}$ to $\mathrm{Fe}^{3+}$ in the presence of hydroperoxides which led to a formation of a color compound between $\mathrm{Fe}^{3+}$ and SCN with some modification [17]. UV-VIS spectrophotometer Camspec, model M 550 (Spectronic CamSpec Ltd, Garforth, UK) was used. One hundred $\mathrm{mg}$ from the extracted lipids were mixed with $50 \mu \mathrm{l} \mathrm{FeCl}_{2}, 50 \mu \mathrm{NH}_{4} \mathrm{SCN}$ and the mixture was brought to a final volume of $10 \mathrm{ml}$ with $\mathrm{CHCl}_{3}$ : $\mathrm{CH}_{3} \mathrm{OH}$ (3: 5, v/ v). After $10 \mathrm{~min}$ in the dark the absorption was measured at $507 \mathrm{~nm}$ against a blank one which did not contain $50 \mu$ of $\mathrm{NH}_{4} \mathrm{SCN}$, POV was calculated by equation (1):

$$
\mathrm{POV}=\frac{\mathrm{A} * 0.0143}{\mathrm{~m} * 55.84 * 2} * 1000, \mathrm{meqO}_{2} / \mathrm{kg}
$$

A - measured absorption at $507 \mathrm{~nm}$;

0.0143 - coefficient of the standard curve;

$\mathrm{m}$ - mass of the samples, $\mathrm{g}$;

55.84 - coefficient of the standard curve;

2 - conversion factor of $\mu \mathrm{eqFe}{ }^{3+}$ to $\mathrm{meqO}_{2}$.

\subsection{Microbiological analysis}

Sample preparation: a basic suspension for microbiological tests has been prepared according to ISO 6887-2: 2004 [18]. Determination of total viable count (TVC): performed by a horizontal method for enumeration of microorganisms in Plate Count Agar (Merck, Germany) and incubation at $30^{\circ} \mathrm{C}$ for $72 \mathrm{~h}$, as described in ISO: 4833: 2013 [19].

\subsection{Sensorial analysis}

The sensory characteristics of the cooked sausages were established by five members' panel according to the recommendations of Meilgaard [20]. A hedonic 5 ball scale was used for this purpose. The appearance, texture, taste, smell, color of the cross-cut surface, were evaluated.

\subsection{Statistical analysis}

The reflection surface method (RSM) was applied to determine the influence of the independent variables and to optimize the process. This method shows the change of the dependent variable $\mathrm{Y}$ when the independent variables change $(x 1, x 2, \ldots, x n)$, therefore the equation of the reflection surface can be expressed as follows:

$$
Y=f(x 1, x 2, \ldots, x n)
$$

To describe processes in food industry a seconddegree polynomial is mostly used as it follows:

$$
\begin{aligned}
& \mathrm{Y}=\mathrm{b}_{\mathrm{o}}+\sum_{\mathrm{i}=1}^{\mathrm{n}} \mathrm{b}_{\mathrm{i}} * \mathrm{x}_{\mathrm{i}}+\sum_{\mathrm{i}=1}^{\mathrm{n}} \mathrm{b}_{\mathrm{ii}} * \mathrm{x}_{\mathrm{i}}^{2}+\sum_{\mathrm{i}=1}^{\mathrm{n}} \sum_{\mathrm{j}=1}^{\mathrm{n}} \mathrm{b}_{\mathrm{ij}} * \\
& \mathrm{x}_{\mathrm{i}} * \mathrm{x}_{\mathrm{J}}
\end{aligned}
$$

where $b_{0}, b_{i}, b_{i i}$ and $b_{i j}$ are the coefficients of the regression equation. For each of the dependent variables an equation in the form of a polynomial is obtained [3]. 


\section{Results and discussion}

The results for $\mathrm{pH}$ value, primary products of lipid oxidation expressed by peroxide value and total viable count of microorganisms are presented in Table 2.

Table 2. $\mathrm{pH}$ and Peroxide values (POV) of the cooked sausages.

\begin{tabular}{|c|c|c|c|c|}
\hline $\begin{array}{c}\text { Design } \\
\text { point }\end{array}$ & pH, 1d & $\mathrm{pH}, 7 \mathrm{~d}$ & $\begin{array}{c}P O V, \\
\mu e q O_{2} / \mathbf{k g}, \\
1 \mathrm{dd}\end{array}$ & $\begin{array}{c}\mathrm{POV}, \\
\mu \mathrm{eq} \mathrm{O}_{2} / \mathrm{kg}, \\
7 \mathrm{~d}\end{array}$ \\
\hline 1 & $\begin{array}{l}6.46^{\mathrm{a}, \mathrm{x}} \\
\pm 0.03\end{array}$ & $\begin{array}{l}6.42^{\mathrm{a}, \mathrm{x}} \\
\pm 0.04\end{array}$ & $\begin{array}{c}1.35^{\mathrm{a}, \mathrm{b}, \mathrm{x}} \\
\pm 0.05\end{array}$ & $\begin{array}{c}2.95^{\mathrm{a}, \mathrm{b}, \mathrm{y}} \\
\pm 0.05\end{array}$ \\
\hline 2 & $\begin{array}{l}6.51^{\mathrm{b}, \mathrm{y}} \\
\pm 0.03\end{array}$ & $\begin{array}{l}6.45^{\mathrm{a}, \mathrm{x}} \\
\pm 0.04\end{array}$ & $\begin{array}{l}1.30^{\mathrm{a}, \mathrm{x}} \\
\pm 0.03\end{array}$ & $\begin{array}{l}3.01^{\mathrm{b}, \mathrm{y}} \\
\pm 0.09\end{array}$ \\
\hline 3 & $\begin{array}{l}6.60^{c, y} \\
\pm 0.03\end{array}$ & $\begin{array}{l}6.47^{\mathrm{a}, \mathrm{x}} \\
\pm 0.04\end{array}$ & $\begin{array}{l}1.31^{\mathrm{a}, \mathrm{x}} \\
\pm 0.02\end{array}$ & $\begin{array}{l}2.88^{\text {a,y }} \\
\pm 0.04\end{array}$ \\
\hline 4 & $\begin{array}{c}6.56^{\mathrm{b}, \mathrm{c}, \mathrm{x}} \\
\pm 0.04\end{array}$ & $\begin{array}{c}6.49^{\mathrm{a}, \mathrm{b}, \mathrm{x}} \\
\pm 0.05\end{array}$ & $\begin{array}{c}1.34^{\mathrm{a}, \mathrm{b}, \mathrm{x}} \\
\pm 0.04\end{array}$ & $\begin{array}{l}2.86^{\mathrm{a}, \mathrm{y}} \\
\pm 0.02\end{array}$ \\
\hline 5 & $\begin{array}{l}6.40^{\mathrm{a}, \mathrm{x}} \\
\pm 0.03\end{array}$ & $\begin{array}{l}6.47^{\mathrm{a}, \mathrm{y}} \\
\pm 0.05\end{array}$ & $\begin{array}{l}1.37^{\mathrm{b}, \mathrm{x}} \\
\pm 0.02\end{array}$ & $\begin{array}{l}2.87^{\mathrm{a}, \mathrm{y}} \\
\pm 0.03\end{array}$ \\
\hline 6 & $\begin{array}{c}6.48^{\mathrm{a}, \mathrm{b}, \mathrm{x}} \\
\pm 0.04\end{array}$ & $\begin{array}{c}6.49^{\mathrm{a}, \mathrm{b}, \mathrm{x}} \\
\pm 0.04\end{array}$ & $\begin{array}{c}1.33^{\mathrm{a}, \mathrm{b}, \mathrm{x}} \\
\pm 0.03\end{array}$ & $\begin{array}{c}2.96^{\mathrm{a}, \mathrm{b}, \mathrm{y}} \\
\pm 0.04\end{array}$ \\
\hline 7 & $\begin{array}{l}6.52^{\mathrm{b}, \mathrm{x}} \\
\pm 0.04\end{array}$ & $\begin{array}{l}6.47^{\mathrm{a}, \mathrm{x}} \\
\pm 0.05\end{array}$ & $\begin{array}{l}1.36^{\mathrm{b}, \mathrm{x}} \\
\pm 0.02\end{array}$ & $\begin{array}{c}2.93^{\mathrm{a}, \mathrm{b}, \mathrm{y}} \\
\pm 0.05\end{array}$ \\
\hline 8 & $\begin{array}{l}6.52^{\mathrm{b}, \mathrm{x}} \\
\pm 0.04\end{array}$ & $\begin{array}{l}6.58^{\mathrm{b}, \mathrm{x}} \\
\pm 0.05\end{array}$ & $\begin{array}{l}1.31^{\mathrm{a}, \mathrm{x}} \\
\pm 0.03\end{array}$ & $\begin{array}{l}2.88^{\text {a,y }} \\
\pm 0.03\end{array}$ \\
\hline 9 & $\begin{array}{l}6.47^{\mathrm{a}, \mathrm{x}} \\
\pm 0.04\end{array}$ & $\begin{array}{c}6.52^{\mathrm{a}, \mathrm{b}, \mathrm{x}} \\
\pm 0.04\end{array}$ & $\begin{array}{l}1.28^{\mathrm{a}, \mathrm{x}} \\
\pm 0.04\end{array}$ & $\begin{array}{c}2.93^{\mathrm{a}, \mathrm{b}, \mathrm{y}} \\
\pm 0.05\end{array}$ \\
\hline
\end{tabular}

$*$ Results are presented as Mean \pm SEM

a,b indicates significant differences $(\mathrm{p} \leq 0.05)$ between Means by columns

${ }^{\mathrm{x}, \mathrm{y}}$ indicates significant differences $(\mathrm{p} \leq 0.05)$ between Means by rows

The generated mathematical model of the second degree (4) shows the correlation between $\mathrm{pH}$ values and concentrations of the used antioxidant substances.

$\mathrm{pH}=6.496+0.021 . \mathrm{x}_{3}+0.023 . \mathrm{x}_{2}+0.022 . \mathrm{x}_{1}-0.010 . \mathrm{x}^{2}$ $+0.010 . \mathrm{x}_{3} . \mathrm{X}_{2}+0.009 . \mathrm{x}_{3} . \mathrm{x}_{1}+0.002 . \mathrm{x}_{2}^{2}-0.001 . \mathrm{X} 2 . \mathrm{X} 1-$ $0.009 . \mathrm{x}^{2}$

On the seventh day of the refrigerated storage the control sample was characterized by the lowest $\mathrm{pH}$ value (6.42) which was $2.37 \%$ lower $(\mathrm{p} \leq 0.05)$ than the one measured in design point 8 (6.58) (Table 2) which contained the triplicate blend of the antioxidants in a concentration of $0.1 \mathrm{~g} / \mathrm{kg}$ (Fig. 1). The model (Fig. 2) shows that on the seventh day of the storage the samples with sodium Lascorbate in combination with dihydroquercetin and/or DDRP were characterized by the $\mathrm{pH}$ values closest to the alkaline region $(\mathrm{pH}>7.00)$ (Table 2).

After seven days of storage at $0-4^{\circ} \mathrm{C}$ there were no statistically significant changes $(\mathrm{p} \leq 0.05)$ in $\mathrm{pH}$ values of cooked sausages prepared with triplicate blend of antioxidants (design points 8 and 9) (Table 1 and 2). The evaluated $\mathrm{pH}$ stabilization during the storage of the studied sausages is very similar to the results reported by Zhang et al. [21] about how the antioxidant activity of vine tea extract affected lipid and protein oxidation in cooked pork patties.

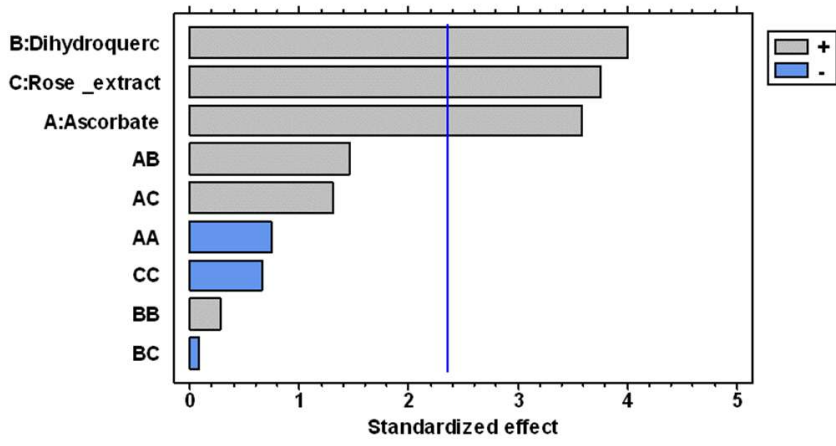

Fig. 1. Pareto chart of standardized effects on $\mathrm{pH}$ values.

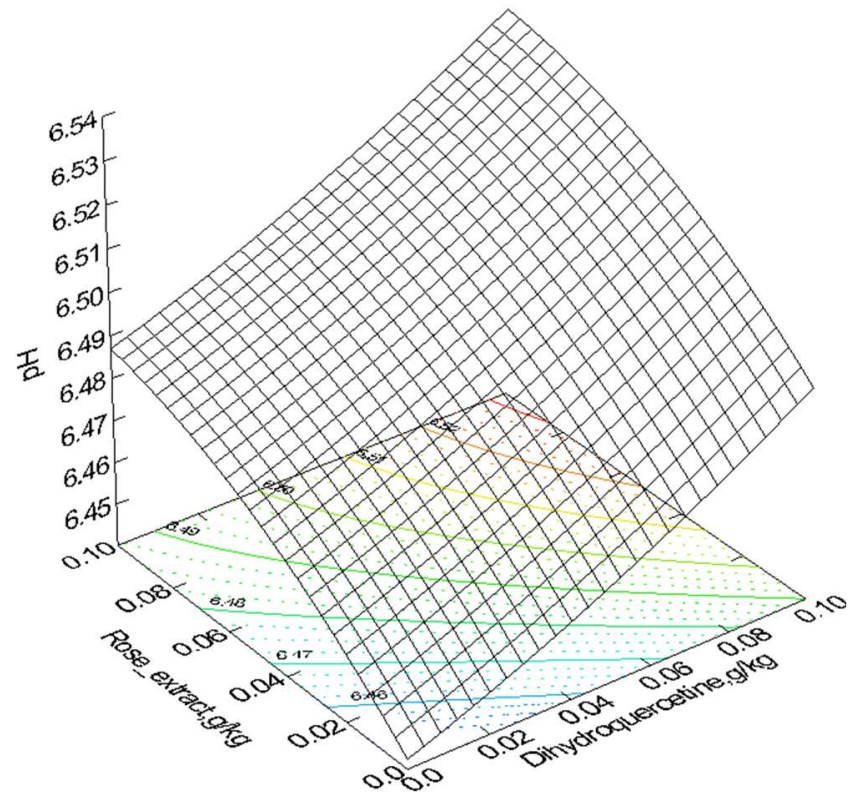

Fig. 2. The surface response charts of $\mathrm{pH}$ values.

An adequate mathematical model of the second degree (5) was determined showing the dependence of the peroxide value on the concentration of added antioxidants:

$\mathrm{POV}=2.944+1.059 . \mathrm{x}_{3}-0.640 . \mathrm{x}_{2}-0.750 . \mathrm{x}_{1}-3.296 . \mathrm{x}^{2}$

$-11.000 . \mathrm{x}_{3} . \mathrm{x}_{2}+0.000 \cdot \mathrm{x}_{3} \cdot \mathrm{x}_{1}+0.704 . \mathrm{x}_{2}^{2}+10.000 . \mathrm{x}_{2} \cdot \mathrm{x}_{1}$

$+0.704 . \mathrm{xi}^{2}, \mu \mathrm{eqO} \mathrm{O}_{2} / \mathrm{kg}$

The POV values on the first day of the experiment there were no statistically significant different $(p \leq 0.05)$ in all design points. After seven days of cold storage the amount of hydroperoxides increased by 2.19 to 2.31 times.

The model shows that the addition of sodium ascorbate at a concentration of $0.1 \mathrm{~g} / \mathrm{kg}$ leads to an increase in the amount of primary products of lipid oxidation (Table 2 and Fig. 3). An inhibitory effect on lipid peroxidation was observed in design points 3 and 5 (Table 1) respectively with $0.1 \mathrm{~g} / \mathrm{kg}$ dihydroquercetin or DDRP extract. The least amounts of hydroperoxides on the first day of storage $0-4^{\circ} \mathrm{C}$ were evaluated in design point 9 (Table 1), prepared with triplicate blend of antioxidants at $0.05 \mathrm{~g} / \mathrm{kg}$ concentrations. 
On the seventh day of the experiment the highest peroxide values were evaluated in design points 2 and 1 (Table 2). It was found that the combination of sodium Lascorbate and dihydroquercetin at concentrations of 0.1 $\mathrm{g} / \mathrm{kg}$ and the triplicate antioxidant blend at concentrations of $0.1 \mathrm{~g} / \mathrm{kg}$ led to the lowest quantities of hydroperoxides (Fig. 4).

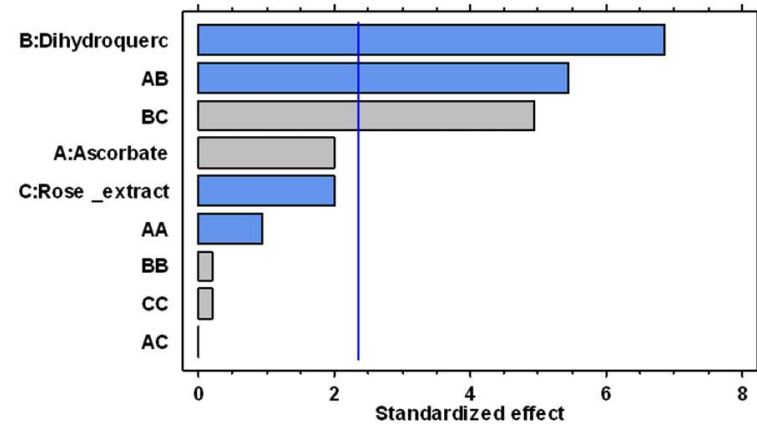

Fig. 3. Pareto chart of standardized effects on peroxide values.

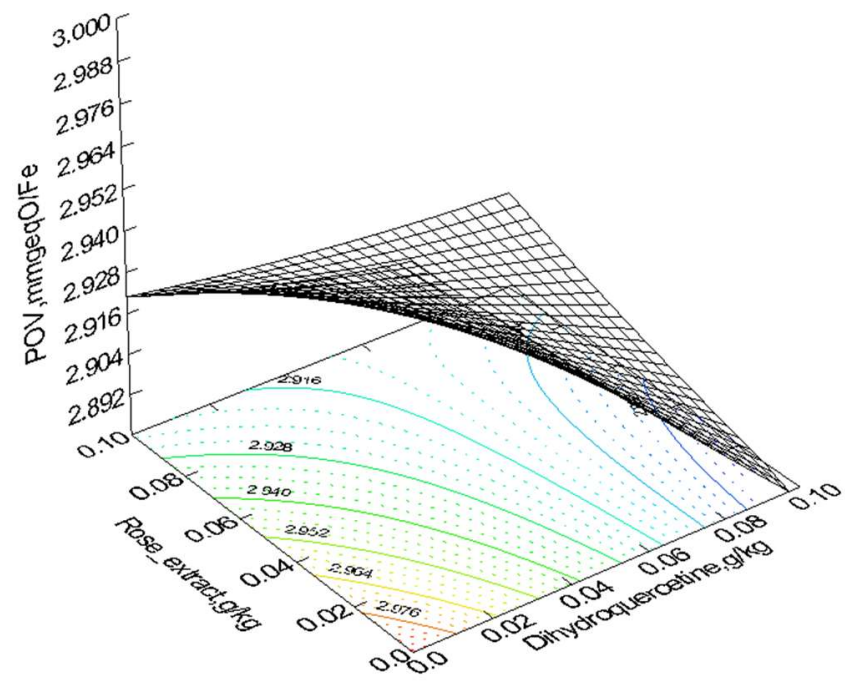

Fig. 4. The surface response charts of peroxide values.

The higher peroxide values at the design points produced with none or single addition of antioxidant substance and the lower values of those containing the triple mixture are in agreement with the hypothesis of a potential synergistic effect. Our results for POV are in agreement with the assumptions of Domínguez et al. [1] and confirm those reported by Cunha et al. [5] regarding the addition of natural antioxidants on the stability of sheep and goat meat products during their processing and storage.

On the first day of the experiment no significant differences between all design points $(\mathrm{p} \leq 0.05)$ were found. After seven days of storage at $0-4^{\circ} \mathrm{C}$ it was established that TVC of microorganisms was not affected by the addition of triplicate blend of antioxidants. Design point 3 (Table 1) prepared solely with $0.1 \mathrm{~g} / \mathrm{kg}$ dihydroquercetin shows the lowest TVC (Fig. 5).

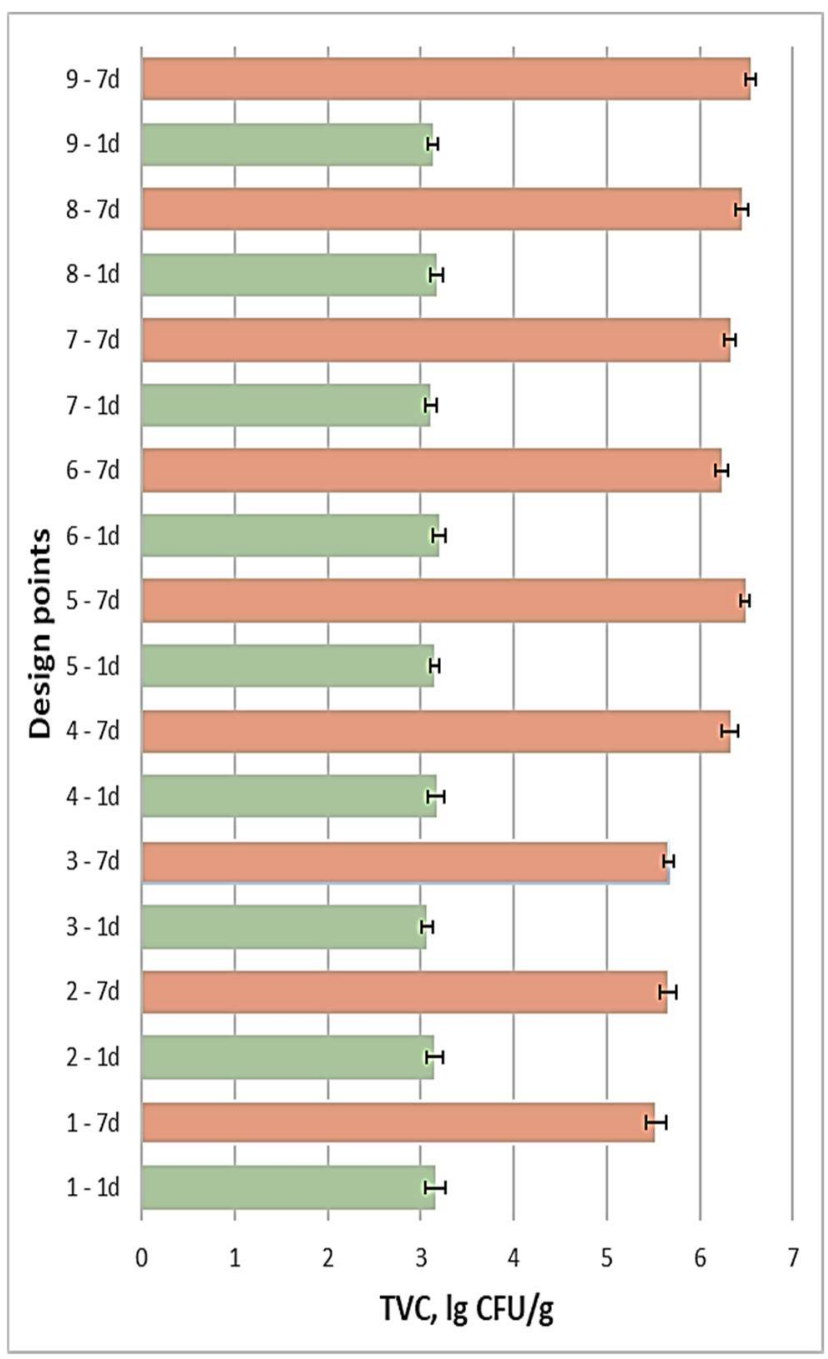

Fig. 5. TVC of the cooked sausages during 7 days of storage at $0-4^{\circ} \mathrm{C}$.

The low TVC (Fig. 5 and Table 3) well correlates with the highest sensory assessed scores of the cooked sausages prepared with $0.5 \mathrm{~g}$ DDRP extract $/ \mathrm{kg}, 0.5 \mathrm{~g}$ dihydroquercetin $/ \mathrm{kg}$ and $0.5 \mathrm{~g}$ sodium L-ascorbate $/ \mathrm{kg}$ (design point 9) (Table 1). The nature of the polyphenolic compounds predisposes them as good antimicrobial agents despite the lack of such a relation with our results [3].

Obviously, the combination between $0.5 \mathrm{~g} / \mathrm{kg}$ of three studied antioxidant substances (DDRP extract, dihydroquercetin, and sodium L-ascorbate/kg (Table 3) was accepted as the best from panelists compared to other eight samples. According to Khramova et al. [2] the addition of dihydroquercetin in meat pates stabilizes their lipid fraction that leads to preserving their quality and sensory characteristics and extending their shelf-life. Similarly, to our results Ivanov et al. [9] used dihydroquercetin to improve the chilled salmon sensory quality. 


\section{Conclusions}

The use of the triplicate blend of natural antioxidants, in lower $(0.05 \mathrm{~g} / \mathrm{kg})$ and higher $(0.1 \mathrm{~g} / \mathrm{kg})$ concentrations largely retains the initial characteristics of cooked sausages after seven days of refrigerated storage.

Table 3. Sensory evaluated scores of the studied samples of cooked sausages.

\begin{tabular}{|c|c|c|c|c|c|}
\hline $\begin{array}{c}\text { Design } \\
\text { points }\end{array}$ & $\begin{array}{c}\text { Appea- } \\
\text { rance }\end{array}$ & Texture & Taste & Smell & $\begin{array}{c}\text { Color of the } \\
\text { cross-cut } \\
\text { surface }\end{array}$ \\
\hline $\mathbf{1}$ & 4 & 5 & 5 & 4 & 5 \\
\hline $\mathbf{2}$ & 4 & 5 & 4 & 4 & 4 \\
\hline $\mathbf{3}$ & 4.5 & 4 & 5 & 4 & 5 \\
\hline $\mathbf{4}$ & 4.5 & 4 & 5 & 4 & 5 \\
\hline $\mathbf{5}$ & 5 & 5 & 5 & 4 & 5 \\
\hline $\mathbf{6}$ & 4.5 & 4 & 5 & 5 & 5 \\
\hline $\mathbf{7}$ & 4 & 4 & 5 & 4 & 4 \\
\hline $\mathbf{8}$ & 4 & 4 & 4 & 4 & 4 \\
\hline $\mathbf{9}$ & 5 & 5 & 5 & 5 & 5 \\
\hline
\end{tabular}

It is assumed that the changes thus established in the studied indicators are a consequence of the manifestation of a synergistic effect in the triple combination of natural antioxidants.

Acknowledgements: This work was supported by the Bulgarian Ministry of Education and Science under the National Research Program "Healthy Foods for a Strong Bio-Economy and Quality of Life" approved by DCM \# 577/17.08.2018.

\section{References}

1. R. Domínguez, M. Pateiro, M. Gagaoua, F.J. Barba, W. Zhang, J.M. Lorenzo, Antioxidants. 8, 429 (2019)

2. J. García-Lomillo, M.L. Gonzalez-SanJose, R. Del Pino-García, M. Ortega-Heras, P. Muñiz-Rodríguez, LWT - Food Sci. Technol. 77, 85-91(2017)

3. A.I. Kalogianni, T. Lazou, I. Bossis, A.I. Gelasakis, Foods. 9, 794, (2020)

4. A. Rustemova, N. Kydyraliev, T. Kirillova, M. Sadygova, N. Batyrbayeva, BIO Web Conf. 27, 00017 (2020)

5. P. Severino, M.H.A. Santana, E.B. Souto, Mater. Sci. Eng. C 32, 1375-1379 (2012)

6. L.C. Cunha, M.L.G. Monteiro, J.M. Lorenzo, P.E. Munekata, V. Muchenje, F.A.L. De Carvalho, C.A. Conte-Junior, Food Res. Int. 111, 379-390 (2018)

7. Y. Kumar, D.N. Yadav, T. Ahmad, K. Narsaiah, Comp. Rev. Food Sci. 14, 796-812 (2015)

8. Regulation (EC) No 1333/2008 - 31.12.2008 of the European Parliament and of the Council of 16 December 2008 on food additives (Off. J. L 354 16, 2008)

9. G. Ivanov, D. Balev, H. Nikolov, S. Dragoev, Bulg. J. Agric. Sci. 15, 154-162 (2009)
10. A. Rokaityte, G. Gintare Zaborskiene, S. Gustiene, R. Raudonis, V. Janulis, G. Galina Garmiene, A. Stimbirys, Czech J. Food Sci. 37, 366-373 (2019)

11. V. Shikov, D. Kammerer, P. Mollov, K. Mihalev, N. Yoncheva, R. Karle, P. Hilendarski Univ. Plovdiv, Sci. Apers - Chem., Collec. A. 36, 59-63 (2008)

12. N.G. Baydar, H. Baydar, Ind. Crop Prod. 41, 375380, (2013)

13. S. Dragoev, D. Vlahova-Vangelova, D Balev, D Bozhilov, S. Dagnon, Bulg. J. Agric. Sci. 27, 209-219 (2021)

14. D. Balev, D. Vlahova-Vangelova, S. Dragoev, Proc. 65th Int. Cong. Meat Sci. Technol. 256, 353-354 (2019)

15. H. Korkeala, O. Mäki-Petäys, T. Alanko, O. Sorvettula, Meat Sci. 18, 121-132 (1986)

16. E.G. Bligh, W.J. Dyer, Can. J. Biochem. Physiol. 37, 911-917 (1959)

17. A.V. Schmedes, G. Hølmer, J. Am. Oil Chem. Soc. 66, 813-817 (1989)

18. ISO 6887-2: 2017. Microbiology of the food chain Preparation of test samples, initial suspension and decimal dilutions for microbiological examination Part 2: Specific rules for the preparation of meat and meat products (ISO, Geneva, 2017)

19. ISO 4833-1: 2013. Microbiology of the food chain Horizontal method for the enumeration of microorganisms - Part 1: Colony count at $30^{\circ} \mathrm{C}$ by the pour plate technique (International Organization for Standardization, Geneva, 2013)

20. M.C. Meilgaard, G.V. Civille, B.T. Carr, Sensory Evaluation Techniques. 3rd ed. (CRC Press, Taylor \& Francis Group, Abingdon, 1999).

21. X. Zhang, Y. Xu, H. Xue, G.C. Jiang, X.J. Liu, Food Sci. Nutr. 7, 1735-1745 (2019)

22. V.N. Khramova, M.I. Slozhenkina, A.N. Burdina, Y.I. Khramova, D.A. Razumov, E.V. Khrapova, E.A. Chekhova, IOP Conf. Ser.: Earth Environ. Sci. 677, 032064 (2021) 